\title{
Spatial and Temporal Sensitivity of Alternaria Species Associated With Potato Foliar Diseases to Demethylation Inhibiting and Anilino-Pyrimidine Fungicides
}

\author{
D. L. Fonseka and N. C. Gudmestad, Department of Plant Pathology, North Dakota State University, Fargo, ND 58108
}

\begin{abstract}
Fonseka, D. L., and Gudmestad, N. C. 2016. Spatial and temporal sensitivity of Alternaria species associated with potato foliar diseases to demethylation inhibiting and anilino-pyrimidine fungicides. Plant Dis. 100:1848-1857.

Early blight and brown spot, caused by Alternaria solani and Alternaria alternata, respectively, are important foliar diseases of potato, affecting both tuber yield and quality. Most of the commercial cultivars lack resistance; therefore, the application of foliar fungicides remains a primary disease management strategy. Baseline sensitivities of A. solani to difenoconazole and metconazole (demethylation inhibitors) using mycelial growth assay exhibited similar intrinsic activity against the pathogen with mean $\mathrm{EC}_{50}$ (the effective concentration at which the fungal growth is inhibited by $50 \%$ ) values of $0.09 \mu \mathrm{g} / \mathrm{ml}$. However, the sensitivity of individual baseline $A$. solani isolates to each fungicide varied substantially, resulting in very low and nonsignificant correlation coefficients among fungicides. Mean $\mathrm{EC}_{50}$ values for baseline A. alternata isolates in response to difenoconazole and metconazole were 0.14 and $0.26 \mu \mathrm{g} / \mathrm{ml}$, respectively. The sensitivity of the majority of $A$. solani

and A. alternata isolates collected from 2010 to 2014 from various potato production states was consistent with baseline isolates, therefore, these potato pathogens remain sensitive to the two demethylation inhibitor chemistries used to manage it. Baseline sensitivity assays of pyrimethanil (anilino-pyrimidine) also indicated great intrinsic activity against both foliar pathogens with mean $\mathrm{EC}_{50}$ values of 0.44 and $0.35 \mu \mathrm{g} / \mathrm{ml}$ for A. solani and A. alternata, respectively. Although $A$. alternata remains largely sensitive to pyrimethanil, 6 out of 245 A. solani isolates collected from 2010 to 2014 exhibited reduced-sensitivity to the fungicide in in vitro assays. Reducedsensitive isolates were not controlled at most pyrimethanil doses except at $100 \mu \mathrm{g} / \mathrm{ml}$ in greenhouse in vivo efficacy tests. These chemistries remain valuable options for fungicide rotation programs in areas of high disease pressure.
\end{abstract}

Alternaria solani Sorauer and A. alternata (Fries.) Keissler cause the potato (Solanum tuberosum L.) foliar diseases early blight and brown spot, respectively. A. solani creates characteristic dark brown to black lesions with concentric rings on older, senescing leaves, which produce a 'target spot' effect, a diagnostic symptom of early blight (Franc and Christ 2001). A. alternata produces similar symptoms and is frequently isolated with $A$. solani in leaf spot-diseased tissue. These ubiquitous diseases are potential threats when potatoes are grown under irrigation and during periods of heavy dew (Rotem 1994). Primary damage is attributed to premature defoliation of the potato plants, resulting in tuber yield reduction. The pathogens may also cause a type of dry rot of tubers, further reducing both the quantity and quality of marketable tubers (Nnodu et al. 1982). The majority of commercially acceptable potato cultivars are susceptible to early blight and brown spot (Franc and Christ 2001) and cultural practices alone are insufficient to reduce the inoculum, thus frequent applications of foliar fungicides are necessary for disease management.

Frequent application of protectant fungicides from early in the growing season until vine-kill are essential under growing conditions prevalent in the midwestern United States, but these are insufficient at high inoculum pressure and conducive environmental conditions (Pasche and Gudmestad 2008). Therefore, the application of locally systemic and translaminar fungicides such as quinone outside inhibitors (QoIs), succinate dehydrogenase inhibitors (SDHIs), demethylation inhibitors (DMIs), and anilino-pyrimidines (APs) is needed to slow the development of an epidemic. The QoI fungicides were first introduced in 1999 on potato and provided excellent disease control (Pasche and Gudmestad 2008; Stevenson and James 1999). Reduced efficacy to QoI fungicides were reported within two years, due to increased selection pressure caused by extensive usage in intensive

Corresponding author: Neil C. Gudmestad;

E-mail: neil.gudmestad@ndsu.edu

Accepted for publication 1 April 2016.

http://dx.doi.org/10.1094/PDIS-01-16-0116-RE

(c) 2016 The American Phytopathological Society production systems (Pasche et al. 2004). SDHI fungicides boscalid and fluopyram were registered for the use on potato in 2005 and 2012, respectively, and became reliable alternatives to QoI fungicides (Gudmestad et al. 2013; Pasche and Gudmestad 2008; Pasche et al. 2005).

The target site of SDHI fungicides is mitochondrial complex II at either the succinate ubiquinone reductase or succinate dehydrogenase complex, which is a functional part of tricarboxylic acid cycle and the mitochondrial electron transport chain (Yin et al. 2011). The frequent use of SDHI fungicides caused resistance to boscalid in various pathosystems, such as A. alternata of peach, pistachio, and potato (Avenot and Michailides 2007; Fairchild et al. 2013; Tymon and Johnson 2014; Yang et al. 2015), Botrytis cinerea of apple (Yin et al. 2011), Didymella bryoniae of watermelon (Thomas et al. 2012), and A. solani of potato (Gudmestad et al. 2013; Tymon and Johnson 2014; Wharton et al. 2012). Current studies demonstrate that $A$. solani isolates resistant to boscalid are not resistant to fluopyram (Fairchild et al. 2013; Gudmestad et al. 2013). However, with other SDHI fungicides registered on potato, such as penthiopyrad and fluxapyroxad, there is a potential for additional cross-resistance among fungicides of the SDHI class (Gudmestad et al. 2013). Therefore, it is likely that the increased use of fluopyram will place significant selection pressure on the early blight pathogen, thus placing additional pressure on other systemic and highly efficacious fungicide chemistries.

First introduced in the 1970s, DMIs are one of four classes of sterol biosynthesis inhibitors having a broad spectrum of activity on a number of fungal pathogens from the Ascomycetes and Basidiomycetes to Fungi imperfecti (Thomas et al. 2012). Difenoconazole is a translaminar fungicide with durable preventive activity during penetration and haustoria formation of phytopathogenic fungi causing various leaf spot diseases, powdery mildews, rust, and scab of annual and perennial crops (Bouwman et al. 2011). Metconazole, another DMI fungicide, has excellent activity on various smut and rust diseases, root rots, and powdery mildews (Friskop et al. 2015). Their mode of action is the inhibition of fungal cell membrane development by preventing ergosterol biosynthesis, thereby causing disruption of membrane function, leakage of cytoplasmic contents, and hyphal inhibition (Bouwman et al. 2011; Brent and Holloman 2007a). Difenoconazole and metconazole were first registered for use on potato in 
2011 and have the potential to be key rotational fungicides in the growers' spray program to control pervasive potato foliar diseases. Currently, little is known about DMI resistance in A. solani and A. alternata pathogen populations.

Pyrimethanil, an anilino-pyrimidine fungicide targeting methionine biosynthesis, was registered on potato for early blight disease control in 2005. Pyrimethanil and other AP fungicides have largely been used to control several pathogens, including B. cinerea (Zhao et al. 2010) and Venturia inaequalis (Köller et al. 2005). The AP fungicides have been classified by the Fungicide Resistance Action Committee (FRAC) as fungicides possessing medium risk of resistance development. However, resistance to AP fungicides has been reported in field isolates of $B$. cinerea of many crops (Amiri et al. 2013; Leroux et al. 1999; Myresiotis et al. 2007), Pecillium spp. of apple and citrus (Kanetis et al. 2008; Xiao et al. 2011), and V. inaequalis of apple (FRAC 2015). Pyrimethanil resistance was first detected in 2010 in Idaho with 19 and $11 \%$ of A. solani and A. alternata isolates, respectively, demonstrating insensitivity to the fungicide (Fairchild et al. 2013). Despite this report, prevalence and impact of pyrimethanil resistance in a diverse pathogen population has yet to be determined.

The incidence of fungicide resistance has grown substantially, due to the introduction of fungicides with a single mode of action (Skylakakis 1982). Due to the countless examples of plant pathogens with reduced sensitivity or resistance to agrochemicals, the plant protection community has taken steps to avoid or delay resistance development in newly developed chemistries, including the formation of FRAC. One of the key elements in resistance management is the establishment of baseline sensitivity and the monitoring of pathogen populations over time (Jutsum et al. 1998; Russell 2005). Further monitoring of a fungal plant pathogen can detect shifts in pathogen sensitivity, predict efficacy of fungicide regimes, and provide information necessary to recommend resistance management tactics (Thomas et al. 2012). The specific objectives of the current study were to determine the difenoconazole, metconazole, and pyrimethanil sensitivity of Alternaria spp. isolates from a baseline population, with isolates collected from a wide potato production area in the midwestern United States, and to determine the effect of any in vitro reduced sensitivity of Alternaria spp. that might be detected on disease control.

\section{Materials and Methods}

$A$. solani and A. alternata isolate collection and maintenance. A. solani and A. alternata isolates that were collected before 2012 were obtained from long-term cryogenic storage (Gudmestad et al. 2013; Pasche et al. 2004). Isolates collected from 2012 to 2014 were obtained from leaf and tuber samples submitted to our laboratory from potato production areas across the nation, including North Dakota, Minnesota, Texas, Nebraska, Michigan, New Mexico, Wisconsin, Colorado, Illinois, Washington, and Idaho. Early blight and brown spot lesions from leaf samples were transferred to $1.5 \%$ agar media and were incubated at room temperature $\left(22 \pm 2^{\circ} \mathrm{C}\right)$ for 3 to 4 days, until conidia were produced (Holm et al. 2003). A single conidium was transferred to a petri plate containing clarified V8 medium (CV-8) (Campbell's V8 juice, $100 \mathrm{ml}$; $\mathrm{CaCO}_{3}, 1.5 \mathrm{~g}$; agar, $15 \mathrm{~g}$; and distilled water, $900 \mathrm{ml}$ ) amended with $50 \mathrm{mg}$ of ampicillin per milliliter. Isolates were incubated under $24 \mathrm{~h}$ of fluorescent light at $22 \pm 2{ }^{\circ} \mathrm{C}$ for a week and were examined for the presence of A. solani or A. alternata conidia (Pasche et al. 2004). For long-term cryogenic storage, 4-mm diameter plugs of media with fungal mycelia and conidia were cut using a sterilized cork borer, and the plugs were placed in screw-top centrifuge tubes. The loosely capped tubes were placed in a closed container with silica gel for 2 to 3 days to remove moisture from the media and then, were capped, sealed with Parafilm, and preserved at $-80^{\circ} \mathrm{C}$ in an ultrafreezer.

In vitro sensitivity to DMI fungicides. DMI sensitivity was determined via mycelial growth assays conducted as described previously in evaluations of D. bryoniae sensitivity to DMI fungicides (Keinath and Hansen 2013). Working cultures were transferred onto CV-8 medium and were incubated under $24 \mathrm{~h}$ of fluorescent light at $22 \pm 2{ }^{\circ} \mathrm{C}$. After 4 days, 5-mm agar plugs were excised from the leading edge of growth and were inverted onto $60 \mathrm{~mm}$ petri plates containing $2 \%$ laboratorygrade agar (A360-500; Fisher Scientific, Pittsburgh, PA) amended with technical grade formulations of difenoconazole (95\% active ingredient [a.i.]) (Syngenta Crop Protection, Greensboro, NC) and metconazole (99\% a.i.) (Valent U.S.A. Corporation, Walnut Creek, CA) dissolved in acetone to reach final concentrations of $0,0.01,0.1,1$, and $10 \mathrm{mg} / \mathrm{ml}$. The final concentration of acetone in all media was $0.1 \%$ by volume. Two perpendicular measurements of mycelial growth for each isolate was measured, with the original plug diameter $(5 \mathrm{~mm})$ subtracted, after incubation at $25 \pm 2{ }^{\circ} \mathrm{C}$ in darkness for 7 days for all the in vitro fungicide sensitivity assays.

Fifty-seven baseline $A$. solani and 50 baseline $A$. alternata isolates were evaluated for in vitro sensitivity to DMI fungicides (Table 1). These isolates were collected from 1998 to 2002 and have had no exposure to DMI fungicides. A. solani isolates collected in 2010 (55 isolates), 2011 (109 isolates), 2012 (eight isolates), 2013 (58 isolates), and 2014 (15 isolates) were also tested for shift in sensitivity to DMI fungicides (Table 1). Additionally, A. alternata isolates collected in 2011 (19 isolates), 2013 (75 isolates), and 2014 (15 isolates) were also tested for sensitivity to DMI fungicides (Table 1).

In vitro sensitivity to pyrimethanil. Fungicide sensitivity was determined via mycelial growth assay on a synthetic medium containing L-asparagine (asp-agar), as described previously for evaluating $B$. cinerea sensitivity to group 9 fungicides (Hilber and Schüepp 1996). Media containing asp-agar were amended with technical grade pyrimethanil ( $95 \%$ a.i.) (Bayer CropScience, Raleigh, NC) dissolved in acetone to reach final concentrations of $0,0.1,1,10$, and $100 \mu \mathrm{g} / \mathrm{ml}$. The highest concentration was not required for baseline evaluations. Five stock solutions were prepared for pyrimethanil sensitivity testing. Asp-agar consisting of $\mathrm{K}_{2} \mathrm{HPO}_{4} \cdot 3 \mathrm{H}_{2} \mathrm{O}(1.31 \mathrm{~g})$ and $\mathrm{MgSO}_{4} \cdot 7 \mathrm{H}_{2} \mathrm{O}$ $(1 \mathrm{~g})$, each dissolved in $30 \mathrm{ml}$ of distilled water, were stocks I and II, respectively. Stock III contained $\mathrm{KCl}(0.5 \mathrm{~g})$ and $\mathrm{FeSO}_{4} \cdot 7 \mathrm{H}_{2} \mathrm{O}$ $(0.01 \mathrm{~g})$ dissolved $30 \mathrm{ml}$ of distilled water. Stock IV was produced by dissolving L-asparagine $(2 \mathrm{~g})$ and agar $(15 \mathrm{~g})$ dissolved in $400 \mathrm{ml}$ of distilled water. Stock V contains $\mathrm{C}_{6} \mathrm{H}_{12} \mathrm{O}_{6} \cdot 1 \mathrm{H}_{2} \mathrm{O}(22 \mathrm{~g})$ dissolved in $490 \mathrm{ml}$ of distilled water. The precipitate that forms when stocks I and II are combined was dissolved by adding $12 \mathrm{M}$ hydrochloric acid dropwise. A precipitate again was observed with the addition of stock III but dissolved with the addition of stock IV. Stock solutions I to IV and stock V were combined after autoclaving, and pyrimethanil was added after cooling.

All Alternaria isolates tested for DMI sensitivity were evaluated also for pyrimethanil sensitivity (Table 1).

Effect of reduced sensitivity of $A$. solani to pyrimethanil on disease control. The significance of an in vitro shift in sensitivity of A. solani to pyrimethanil on disease control was determined under greenhouse conditions, as previously described (Gudmestad et al. 2013; Pasche et al. 2004, 2005). A subset of six isolates of A. solani was tested for in vivo studies based on in vitro pyrimethanil sensitivity. Two sensitive and four pyrimethanil reduced-sensitive isolates were used. All isolates were recovered from long-term storage and were maintained, and conidia were harvested.

The in vivo sensitivity assay was conducted as a $24-\mathrm{h}$ preventive test. Pyrimethanil was applied $24 \mathrm{~h}$ prior to inoculation in the greenhouse using tomato plants, cv. Orange Pixie VFT hybrid (Tomato Growers Supply Company, Fort Myers, FL). This cultivar was used because of its susceptibility to early blight and compact size compared with potato plants. This allowed for adequate replication for evaluating multiple fungicide concentrations across several $A$. solani isolates. Three tomato seeds were sown in each $10-\mathrm{cm}^{3}$ plastic pot containing Sunshine Mix LC1 (Sun Gro Horticulture Inc., Bellevue, WA), and after emergence, plants were thinned to obtain two uniformly sized plants per pot. When the first three leaves were fully expanded and plants had reached a height of 15 to $20 \mathrm{~cm}$, plants were treated with a commercial formulation of pyrimethanil (37.4\% a.i.) (Scala 400 SC; Bayer). Ten-fold fungicide concentrations of the active ingredient were applied to the plants $(0,0.1,1,10$, and 100 $\mu \mathrm{g} / \mathrm{ml}$ ) to obtain a dose response curve. Fungicide was applied using a Generation II research sprayer (Devries Manufacturing, Hollandale, $\mathrm{MN}$ ) at approximately $400 \mathrm{kPa}$. At $24 \mathrm{~h}$ after fungicide application, plants were inoculated, using $50 \mathrm{ml}$ of a $2.0 \times 10^{5}$ conidia per milliliter suspension produced from 10- to 12-day-old-cultures of $A$. solani maintained on CV-8 medium for 7 to 14 days under $24 \mathrm{~h}$ 
fluorescent light at $22 \pm 2^{\circ} \mathrm{C}$. A Preval paint-spray gun (Preval Sprayer Division; Precision Valve Corporation, Yonkers, NY) was used for inoculation, and inoculated plants were kept in individual humidity chambers (Phytotronic Inc., Earth City, MO) (1626D) for

Table 1. Origin of Alternaria spp. isolates used in in vitro fungicide sensitivity assays from 1998 to 2014

\begin{tabular}{|c|c|c|c|}
\hline Year & State of origin & $\begin{array}{l}\text { No. of Alternaria } \\
\text { solani isolates }\end{array}$ & $\begin{array}{l}\text { No. of Alternaria } \\
\text { alternata isolates }\end{array}$ \\
\hline \multirow[t]{7}{*}{$1998^{z}$} & Idaho & 2 & - \\
\hline & Minnesota & 5 & - \\
\hline & Nebraska & 13 & - \\
\hline & North Dakota & 1 & - \\
\hline & South Dakota & 1 & - \\
\hline & Texas & 1 & - \\
\hline & Wisconsin & 1 & - \\
\hline \multirow[t]{7}{*}{$1999^{z}$} & Colorado & - & 1 \\
\hline & Idaho & - & 1 \\
\hline & Minnesota & - & 3 \\
\hline & Nebraska & - & 1 \\
\hline & New Mexico & - & 6 \\
\hline & North Dakota & - & 1 \\
\hline & Texas & - & 11 \\
\hline \multirow[t]{5}{*}{$2000^{z}$} & Idaho & - & 3 \\
\hline & Minnesota & - & 1 \\
\hline & North Dakota & - & 8 \\
\hline & Texas & - & 1 \\
\hline & Wisconsin & - & 1 \\
\hline \multirow[t]{3}{*}{$2001^{z}$} & Minnesota & 5 & - \\
\hline & Nebraska & 17 & - \\
\hline & North Dakota & 11 & 3 \\
\hline \multirow[t]{4}{*}{$2002^{z}$} & Minnesota & - & 1 \\
\hline & Nebraska & - & 1 \\
\hline & North Dakota & - & 6 \\
\hline & Texas & - & 1 \\
\hline \multirow[t]{3}{*}{2010} & Idaho & 27 & - \\
\hline & Nebraska & 12 & - \\
\hline & North Dakota & 16 & - \\
\hline \multirow[t]{8}{*}{2011} & Colorado & 4 & - \\
\hline & Florida & 2 & - \\
\hline & Idaho & 15 & 3 \\
\hline & Minnesota & 29 & 2 \\
\hline & Nebraska & 31 & 1 \\
\hline & North Dakota & 10 & 13 \\
\hline & Texas & 15 & - \\
\hline & Wisconsin & 3 & - \\
\hline \multirow[t]{5}{*}{2012} & Colorado & 1 & - \\
\hline & Idaho & 1 & - \\
\hline & Nebraska & 3 & - \\
\hline & Texas & 2 & - \\
\hline & Wisconsin & 1 & - \\
\hline \multirow[t]{12}{*}{2013} & California & - & 6 \\
\hline & Colorado & 9 & 7 \\
\hline & Idaho & 1 & 5 \\
\hline & Illinois & 2 & 21 \\
\hline & New Mexico & 4 & 8 \\
\hline & Michigan & 2 & - \\
\hline & Minnesota & 8 & 1 \\
\hline & Nebraska & 5 & 9 \\
\hline & North Dakota & 11 & 5 \\
\hline & Texas & 10 & 11 \\
\hline & Washington & 1 & 1 \\
\hline & Wisconsin & 5 & 1 \\
\hline \multirow[t]{5}{*}{2014} & Idaho & 1 & 4 \\
\hline & Michigan & 1 & - \\
\hline & Nebraska & 3 & - \\
\hline & North Dakota & 2 & - \\
\hline & Texas & 8 & 11 \\
\hline
\end{tabular}

${ }^{\mathrm{z}}$ Alternaria solani and Alternaria alternata isolates collected from 1998 to 2002 had no exposure to demethylation inhibitor (DMI) and anilino-pyrimidine (AP) fungicides and, hence, are categorized as baseline isolates.
$24 \mathrm{~h}$ at $>95 \%$ relative humidity and $22 \pm 2{ }^{\circ} \mathrm{C}$. Plants were transferred to confinement chambers (plastic chambers with open ceilings) on greenhouse benches, to avoid cross contamination among A. solani isolates, and were maintained at $25 \pm 2{ }^{\circ} \mathrm{C}$ with daily application of water. Early blight disease severity was rated visually at 6,9 , and 12 days postinoculation by estimating the percentage of infected leaf area of the first three true leaves (three subsamples), recorded as percentage of diseased tissue. Two samples (two plants per pot) and three replications (three pots) were tested for each isolate $\times$ fungicide concentration. The in vivo experiment was performed three times.

Statistical analyses. All in vitro experiments were performed twice in completely random design with two replicates for each fungicide concentration. To determine the $\mathrm{EC}_{50}$ value (effective concentration at which the fungal growth is inhibited by 50\%) for each isolate, the percent reduction in mycelial growth relative to the nontreated control was calculated (Pasche et al. 2004). These data were regressed against the $\log _{10}$ fungicide concentration, and the $\mathrm{EC}_{50}$ value was determined by interpolation of $50 \%$ intercept, using the Statistical Analysis System (SAS Institute Inc., Cary, NC). The experiments were analyzed separately, and the F test was used to test for homogeneity of variance among experiments. In all in vitro studies involving A. alternata, the coefficient of variability (standard error/mean) of log-10 transformed $\mathrm{EC}_{50}$ values among all experimental repeats was calculated as a measure of assay reproducibility (Thomas et al. 2012). In all in vitro studies involving A. solani, control isolates 13-1, a wild-type A. solani isolate, and 526-3, a QoI resistant isolate, were used in each trial as internal controls to determine reproducibility of the assay. Assay reproducibility calculations were applied to the internal controls (Wong and Wilcox 2002). The assay reproducibility calculations generated approximate limits for $95 \%$ confidence interval for the two internal controls. Trials in which the $\mathrm{EC}_{50}$ values of the internal controls are within the $95 \%$ confidence interval were included in further statistical analyses. Correlation analysis $(\alpha=0.05)$ was performed using Pearson correlation coefficients to compare in vitro fungicide $\mathrm{EC}_{50}$ values for both baseline and 2010 to 2014 A. solani and A. alternata isolates. A resistance factor $(\mathrm{Rf})$ was calculated for each fungicide by dividing the $\mathrm{EC}_{50}$ value of an individual isolate by the mean baseline $\mathrm{EC}_{50}$ value for the Alternaria species being evaluated.

All in vivo experiments were split-plot randomized complete block designs with $A$. solani isolates as the main plot and fungicide concentrations as split-plots. For each isolate, at all fungicide concentrations, disease severity data were transformed to percent disease control, using the formula $1-(\%$ diseased tissue $/ \%$ diseased tissue in nontreated plants) $\times 100$. Levene's test was conducted to test for homogeneity of variance among three independent experiments (Milliken and Johnson 1992). The analysis of variance (ANOVA) was performed separately for isolate $\times$ fungicide group combination at each fungicide concentration using SAS, and $t$ tests were used on the combined data to detect differences at each fungicide concentration. Area under the disease progress curve for dose-response curves were calculated to determine if there is a significant difference in disease control provided by pyrimethanil in controlling sensitive and reduced-sensitive isolates (Shaner and Finney 1977).

\section{Results}

Determination of baseline in vitro sensitivity of $A$. solani and A. alternata to difenoconazole, metconazole, and pyrimethanil. Experimental variances were homogenous $(P=0.05)$ for $\mathrm{EC}_{50}$ values calculated from in vitro fungicide sensitivity experiments. $\mathrm{EC}_{50}$ values of the $A$. solani isolate sensitivity to difenoconazole and metconazole ranged from 0.02 to 0.30 and 0.04 to $0.18 \mu \mathrm{g} / \mathrm{ml}$, respectively, with a mean $\mathrm{EC}_{50}$ value of $0.09 \mu \mathrm{g} / \mathrm{ml}$ to each fungicide (Fig. 1A). $\mathrm{EC}_{50}$ values of the A. alternata isolate sensitivity to difenoconazole and metconazole ranged from 0.03 to 0.33 and 0.04 to $0.48 \mu \mathrm{g} / \mathrm{ml}$ with mean $\mathrm{EC}_{50}$ values of 0.14 and 0.26 , respectively (Fig. 1B). The correlation coefficient comparing $\mathrm{EC}_{50}$ values for difenoconazole and metconazole baseline sensitivities of individual $A$. solani isolates was very low $(r=0.0205)$, indicating that the association between these two fungicides was very weak and not significant 
$(P=0.8797)$ (Fig. 2A). In contrast, the correlation analysis disclosed a positive and statistically significant association between $\mathrm{EC}_{50}$ values for difenoconazole and metconazole baseline sensitivities among individual $A$. alternata isolates $(r=0.7141, P<0.0001)$ (Fig. 2B).

$\mathrm{EC}_{50}$ values of the $A$. solani isolate sensitivity for pyrimethanil ranged from 0.35 to $0.58 \mu \mathrm{g} / \mathrm{ml}$ with a mean $\mathrm{EC}_{50}$ value of 0.44 (Fig. 1C). $\mathrm{EC}_{50}$ values for baseline sensitivity of $A$. alternata isolates to pyrimethanil ranged from 0.15 to $0.42 \mu \mathrm{g} / \mathrm{ml}$, with mean $\mathrm{EC}_{50}$ value of 0.35 (Fig. 1C).

Determination of in vitro sensitivity of $A$. solani isolates collected from 2010 to 2014. Independent ANOVA of in vitro fungicide sensitivity experiments for difenoconazole, metconazole, and pyrimethanil $\mathrm{EC}_{50}$ values determined that error variances were homogenous $(P=0.05)$; thus, experiments were combined by individual fungicides. $\mathrm{EC}_{50}$ values of $A$. solani isolate sensitivity to difenoconazole and metconazole ranged from 0.05 to 0.35 and 0.04 to $0.42 \mu \mathrm{g} / \mathrm{ml}$, respectively. The overall mean fungicide sensitivities of the fifty-five $2010 \mathrm{~A}$. solani isolates to difenoconazole and metconazole were 0.12 and $0.18 \mu \mathrm{g} / \mathrm{ml}$, respectively (Fig. 3A). Mean $\mathrm{EC}_{50}$ values for the 109 isolates from 2011 were 0.13 and $0.19 \mu \mathrm{g} / \mathrm{ml}$ for difenoconazole and metconazole, respectively. Eight isolates from 2012 had mean $\mathrm{EC}_{50}$ values of 0.14 and $0.25 \mu \mathrm{g} / \mathrm{ml}$ for difenoconazole and metconazole, respectively (Fig. 3A). Mean $\mathrm{EC}_{50}$ values for the 58 isolates from 2013 were 0.07 and $0.16 \mu \mathrm{g} / \mathrm{ml}$ for difenoconazole and metconazole, respectively, while 15 isolates from 2014 had mean $\mathrm{EC}_{50}$ values of 0.06 and $0.10 \mu \mathrm{g} / \mathrm{ml}$ for difenoconazole and metconazole (Fig. 3A).

Individual analysis of $A$. solani isolate $\mathrm{EC}_{50}$ values for each fungicide revealed a significant difference between the mean $\mathrm{EC}_{50}$ value
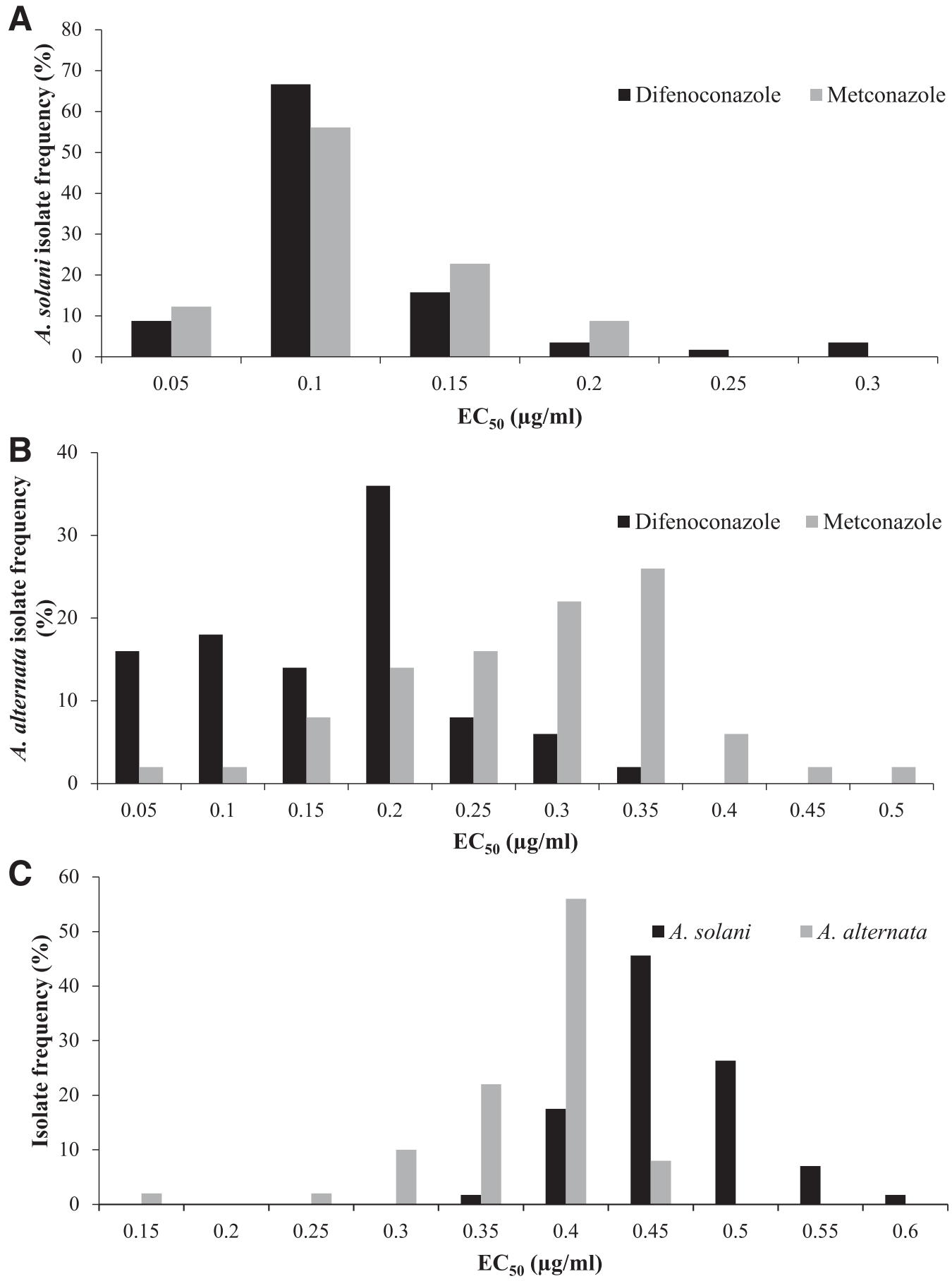

Fig. 1. Frequency distribution of sensitivity of A, 57 baseline Alternaria solani isolates to demethylation inhibitor (DMI) fungicides, B, 50 baseline Alternaria alternata isolates to DMI fungicides, and C, Alternaria spp. isolates to pyrimethanil, based on in vitro methods to determine the effective concentration that inhibits mycelial growth by $50 \%$ compared with the nontreated control $\left(\mathrm{EC}_{50} \mathrm{\mu g} / \mathrm{ml}\right)$. These isolates were collected from 1998 to 2002 from several potato production areas in the United States. 
of baseline and fungicide-exposed isolates for both difenoconazole and metconazole $(P=0.0228$ and $P<0.0001)$, respectively (Fig. $3 \mathrm{~A})$. In this study, the $\mathrm{Rf}$ values for $A$. solani sensitivity testing were 1.2 and 2.0, respectively, for difenoconazole and metconazole. Isolates collected in 2012 had significantly higher $\mathrm{EC}_{50}$ values for metconazole than each of the preceding years, while isolates collected in $2012 \mathrm{had}$ the highest $\mathrm{EC}_{50}$ value for difenoconazole, and isolates collected in 2014 had the lowest $\mathrm{EC}_{50}$ value for difenoconazole sensitivity, relative to isolates collected in other years (Fig. 3A). In contrast to the baseline A. solani isolates, correlation analysis disclosed a significant association between $\mathrm{EC}_{50}$ values for difenoconazole and metconazole sensitivities of individual A. solani isolates collected from 2010 to 2014 ( $r=0.4962, P<0.0001$ ) (Fig. 4A). However, the difference may be due to the number of isolates used in the baseline $(n=57)$ and nonbaseline $(n=245)$ sensitivity testing.

$\mathrm{EC}_{50}$ values of the $A$. solani isolate sensitivity for pyrimethanil ranged from 0.36 to $28.26 \mu \mathrm{g} / \mathrm{ml}$. The overall mean pyrimethanil sensitivity for the 55 A. solani isolates collected in 2010 was $0.74 \mu \mathrm{g} / \mathrm{ml}$ (Fig. 5). The mean $\mathrm{EC}_{50}$ value for the 109 isolates from 2011 was $0.95 \mu \mathrm{g} / \mathrm{ml}$, while eight isolates from 2012 had a mean $\mathrm{EC}_{50}$ value of $0.50 \mu \mathrm{g} / \mathrm{ml}$ (Fig. 5). The mean $\mathrm{EC}_{50}$ value for the 58 isolates from 2013 was $0.54 \mu \mathrm{g} / \mathrm{ml}$, while 15 isolates from 2014 had a mean $\mathrm{EC}_{50}$ value of $0.57 \mu \mathrm{g} / \mathrm{ml}$ (Fig. 5). Although there was no significant $(P=$ 0.4453 ) difference between mean $\mathrm{EC}_{50}$ value of baseline and fungicide exposed isolates (Fig. 5), six A. solani isolates had $\mathrm{EC}_{50}$ values greater than mean baseline value by fourfold (Table 2).

Determination of in vitro sensitivity of $A$. alternata isolates collected from 2011 to 2014. Independent ANOVA of in vitro fungicide sensitivity experiments for difenoconazole, metconazole, and pyrimethanil $\mathrm{EC}_{50}$ values determined that error variances were homogenous $(P=0.05)$; thus, experiments were combined by individual fungicides. $\mathrm{EC}_{50}$ values of the $A$. alternata isolate sensitivity to difenoconazole and metconazole ranged from 0.03 to 0.28 and 0.05 to $0.46 \mu \mathrm{g} / \mathrm{ml}$, respectively. The overall mean fungicide sensitivities of the nineteen 2011 A. alternata isolates to difenoconazole and metconazole were 0.12 and $0.20 \mu \mathrm{g} / \mathrm{ml}$, respectively (Fig. 3B). Mean $\mathrm{EC}_{50}$ values for the 75 isolates from 2013 were 0.12 and $0.18 \mu \mathrm{g} / \mathrm{ml}$ for difenoconazole and metconazole, respectively, while 15 isolates from 2014 had mean $\mathrm{EC}_{50}$ values of 0.07 and $0.12 \mu \mathrm{g} / \mathrm{ml}$ for difenoconazole and metconazole (Fig. 3B). Individual analysis of $A$. alternata isolate $\mathrm{EC}_{50}$ values for each fungicide revealed a significant difference between mean $\mathrm{EC}_{50}$ value of baseline and fungicide-exposed isolates for both difenoconazole and metconazole $(P=0.0020$ and $P<0.0001)$, respectively (Fig. 3B). In this study, the $\mathrm{Rf}$ values for $A$. alternata sensitivity testing were 0.8 and 0.7 , respectively, for difenoconazole and metconazole. Similar to baseline A. alternata isolates, correlation analysis disclosed a significant association between $\mathrm{EC}_{50}$ values for difenoconazole and metconazole sensitivities among individual A. alternata isolates collected from 2011 to 2014 ( $r=0.8673, P<0.0001$ ) (Fig. 4B).

A. alternata isolates collected from 2011 to 2014 were tested for pyrimethanil sensitivity with significant differences observed between mean $\mathrm{EC}_{50}$ values of baseline and nonbaseline (fungicide-exposed) isolates $(P<0.0001)$ (Fig. 5). $\mathrm{EC}_{50}$ values of the A. alternata isolate sensitivity for pyrimethanil ranged from 0.31 to $1.27 \mu \mathrm{g} / \mathrm{ml}$. The overall mean pyrimethanil sensitivity for 19 A. alternata isolates collected in 2011 was $0.52 \mu \mathrm{g} / \mathrm{ml}$ (Fig. 5). The mean $\mathrm{EC}_{50}$ value for the 75 isolates from 2013 was $0.47 \mu \mathrm{g} / \mathrm{ml}$, while 15 isolates from 2014 had a mean $\mathrm{EC}_{50}$ value of $0.61 \mu \mathrm{g} / \mathrm{ml}$ (Fig. 5). In this study, the Rf value for $A$. alternata sensitivity testing was 1.4 for pyrimethanil.

Effect of reduced-sensitivity of $A$. solani to pyrimethanil on disease control. Independent analysis of in vivo disease control experiments for pyrimethanil determined that variances were homogenous $(P=0.05)$; thus, experiments were combined for further analysis. A significant interaction between the main plot (isolate) and subplot factor (fungicide concentrations) $(P<0.0001)$ was observed for percentage disease control of pyrimethanil on $A$. solani-infected greenhousegrown tomato plants. Significant effects $(P<0.0001)$ were also
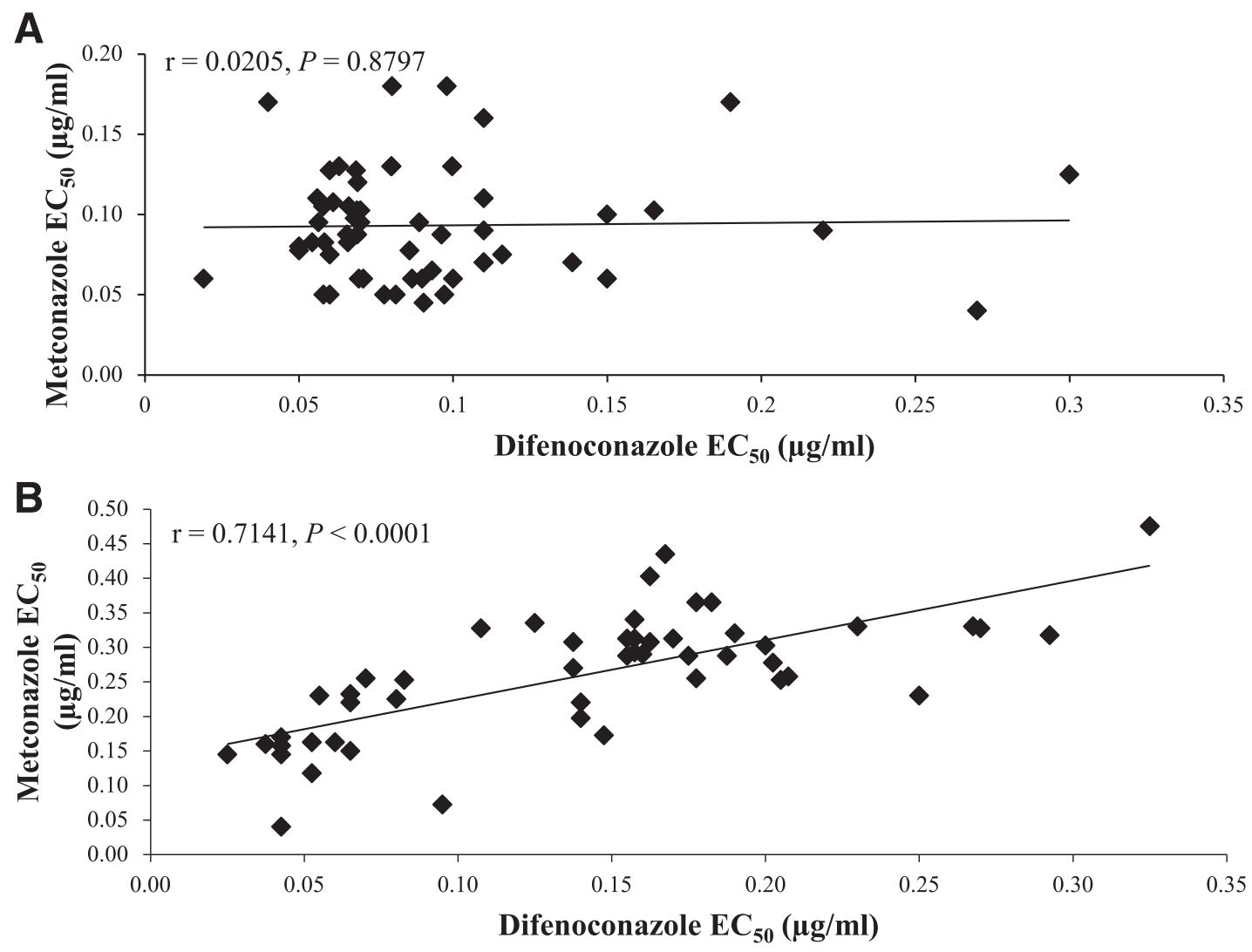

Fig. 2. Linear correlation between A, in vitro difenoconazole and metconazole sensitivity of 57 baseline Alternaria solani isolates and B, in vitro difenoconazole and metconazole sensitivity of 50 baseline Alternaria alternata isolates. 

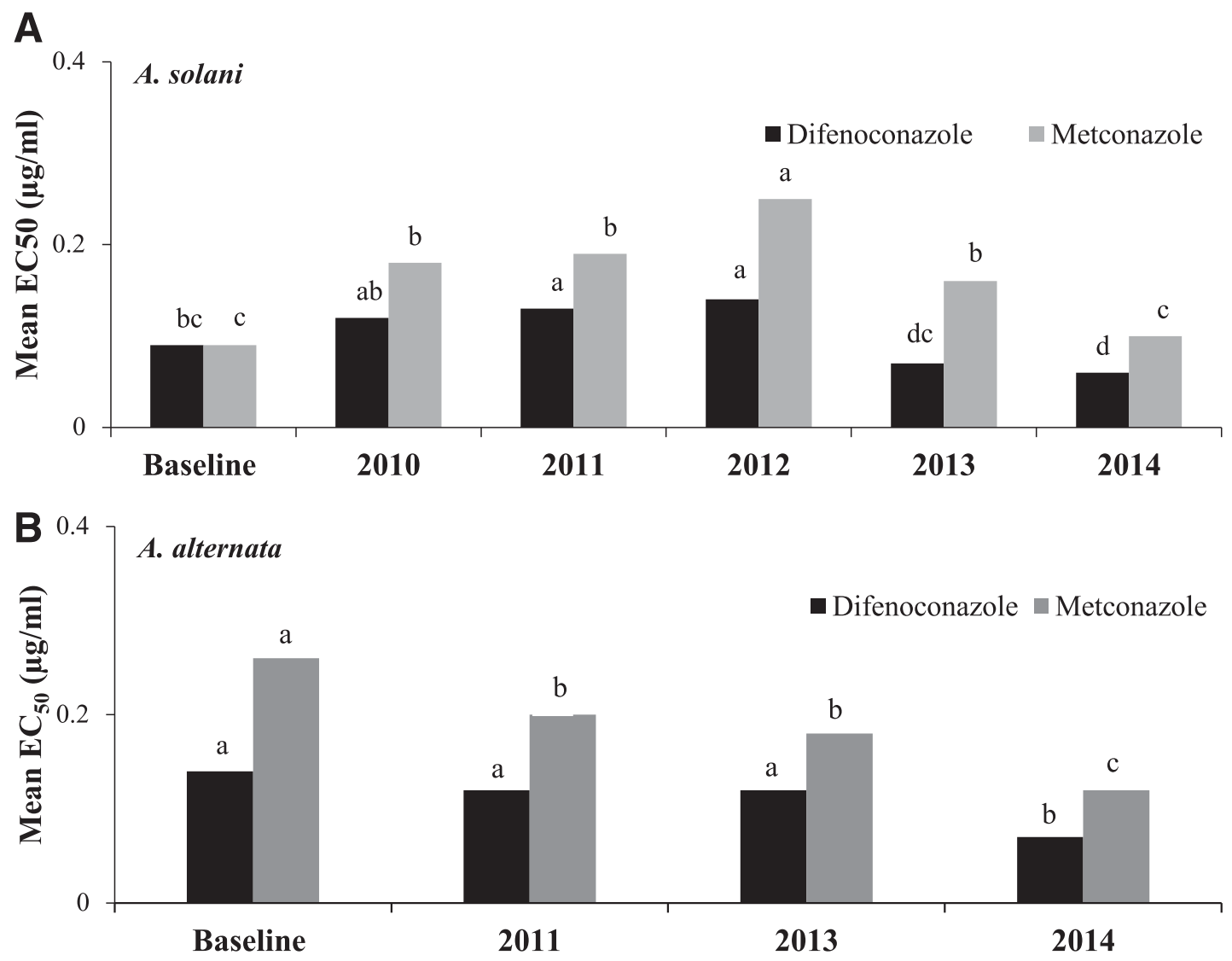

Fig. 3. Mean $\mathrm{EC}_{50}$ (the effective concentration at which the fungal growth is inhibited by $50 \%$ ) values for in vitro isolate sensitivity of A, Alternaria solani and B, Alternaria alternata to demethylation inhibitor fungicides across years. Within fungicides, columns with the same letter are not significantly different, based on Fisher's protected least significant difference at the $P=0.05$ level. In vitro $\mathrm{EC}_{50}$ values were not determined for $A$. alternata isolates for 2010 and 2012 due to lack of brown spot-infected potato samples sent to the laboratory.
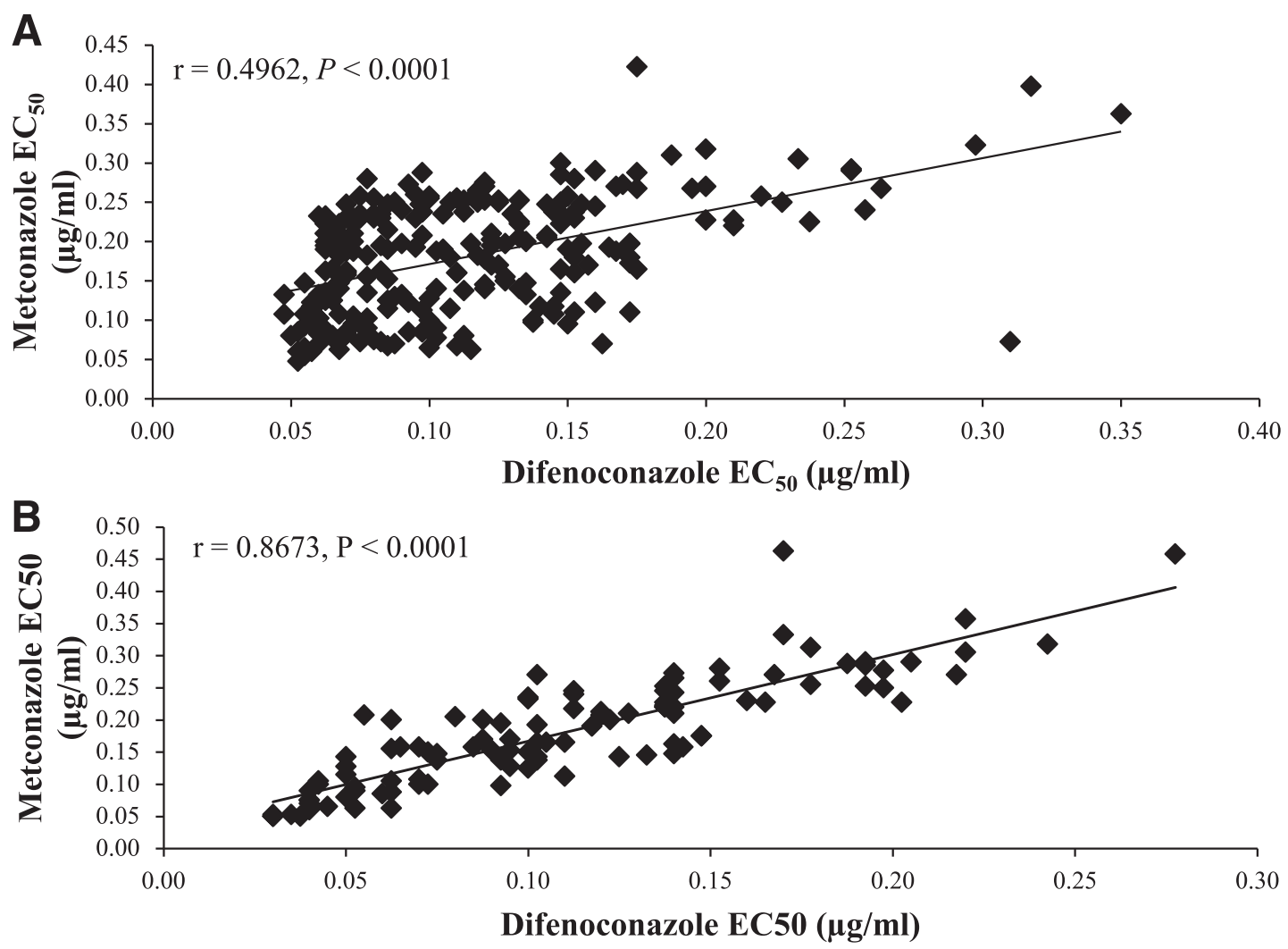

Fig. 4. Linear correlation between A, in vitro difenoconazole and metconazole sensitivity of 245 Alternaria solani isolates collected from 2010 to 2014 and B, in vitro difenoconazole and metconazole sensitivity of 109 Alternaria alternata isolates collected from 2011 to 2014. 
observed for isolate and fungicide concentration for percent disease control. Dose response curves indicate that sensitive $A$. solani isolates (13-1 and 1179-3) were controlled similarly at all fungicide concentrations except $1 \mu \mathrm{g} / \mathrm{ml}$ (Table 3; Fig. 6). Significant differences were observed in the disease control of reduced-sensitive isolates (1168-3, 1184-14, 1191-13, and 1332-6) at concentrations of 0.1, 1, and 10 $\mu \mathrm{g} / \mathrm{ml}$ (Table 3). For all concentrations, disease control of reducedsensitive isolates of $A$. solani was significantly less than the disease control provided by pyrimethanil on sensitive isolates (Table 3 ).

\section{Discussion}

This is the first report of monitoring sensitivity levels of $A$. solani and $A$. alternata populations to difenoconazole, metconazole, and pyrimethanil across multiple years and production areas. The two DMI fungicides were registered in 2011 for use on potato, but pyrimethanil has been used by growers for the management of early blight and brown spot for almost 10 years. The in vitro sensitivities of the fungicides described in this study are based on $\mathrm{EC}_{50}$ values derived from the inhibition of mycelial growth. Assays developed in other pathogen systems have successfully used this method (Bolton et al. 2012; Hilber and Schüepp 1996). DMI fungicides and pyrimethanil inhibit mycelial growth of fungal pathogens, the development stage related to progression and proliferation of subcuticular stromata but cause no inhibition of spore germination (Daniels and Lucas 1995; Smith et al. 1991). It has been determined previously that complex media such as malt agar was not suitable for in vitro assays of AP fungicides if mycelial plugs are used as inoculum from agar plates that have been incubated for more than $23 \mathrm{~h}$ (Hilber and Schüepp 1996). In that study, the incubation period of the inoculum did not affect the activity of anilino-pyrimidines, when asp-agar was used. Therefore, the synthetic medium containing asp-agar was used for in vitro pyrimethanil testing in this study.

Baseline isolates of $A$. solani and A. alternata used in this study had relatively high levels of variability in response to difenoconazole, with the difference between the most- and least-sensitive isolates being 15- and 11-fold, respectively. Similarly, wider distribution (45-fold) was reported in the sensitive $V$. inaequalis isolates (Villani et al. 2015). However, the distribution ranges of difenoconazole sensitivity reported in Cercospora beticola (Bolton et al. 2012), Colletotrichum coccodes (Olaya et al. 2010), and D. bryoniae (Thomas et al. 2012) were narrow, displaying limited variation within baseline isolates. A few reports assessing in vitro fungicide sensitivity of metconazole on other fungal pathogens are available. The range of $\mathrm{EC}_{50}$ values for metconazole was narrow for baseline $A$. solani isolates (4.5-fold) and was similar to that reported in Galactomyces geotrichum (McKay et al. 2012). The range of sensitivity of Fusarium graminearum isolates in response to metconazole was higher (17.2-fold) than what this study reports for $A$. solani; however, since those Fusarium isolates had previous exposure to tebuconazole, this does not constitute a valid baseline group for Fusarium graminearum and a wider range of values could be expected from such a population (Spolti et al. 2014). In the baseline sensitivity established in the current study for A. alternata, there is a 12-fold difference in sensitivity from the most metconazole-sensitive isolate to the least sensitive. The distribution of pyrimethanil sensitivity of baseline A. solani and A. alternata isolates in this study was narrow and is comparable with ranges of $\mathrm{EC}_{50}$ values reported in B. cinerea (Sun et al. 2010) and $V$. inaequalis (Köller et al. 2005) but is unlike the wider distribution reported in a Penicillium sp. (Sholberg et al. 2005).

The two DMI fungicides, difenoconazole and metconazole, appear to exhibit great intrinsic activity against both $A$. solani and A. alternata, perhaps due to the postinfection activity reported for these fungicides (Wong and Midland 2007). The sensitivity of the majority of A. solani and A. alternata isolates collected from 2010 to 2014 was consistent with baseline isolates; therefore, these isolates remain sensitive to the two DMI chemistries. Some baseline isolates of $A$. solani and $A$. alternata had high DMI $\mathrm{EC}_{50}$ values, which may be due to some level of reduced sensitivity already present in the population but not present in the isolates we have available to us. The high $\mathrm{EC}_{50}$ values might also be due to the great amount of variation in morphology, physiology, genetic makeup, and pathogenicity among Alternaria spp. isolates, despite having only an asexual life cycle (Aradhya et al. 2001; van der Waals et al. 2004; Woudenberg et al. 2015). In vivo trials were not conducted assessing disease control provided by these fungicides, as previous studies have demonstrated that two- to fourfold changes in Rf values in A. solani do not affect early blight disease control under greenhouse conditions (Gudmestad et al. 2013; Pasche et al. 2004, 2005). It should be noted, however, that DMIs are not the primary 'specialty' fungicides used to manage early blight. Instead, tank mixtures of QoIs and SDHIs with

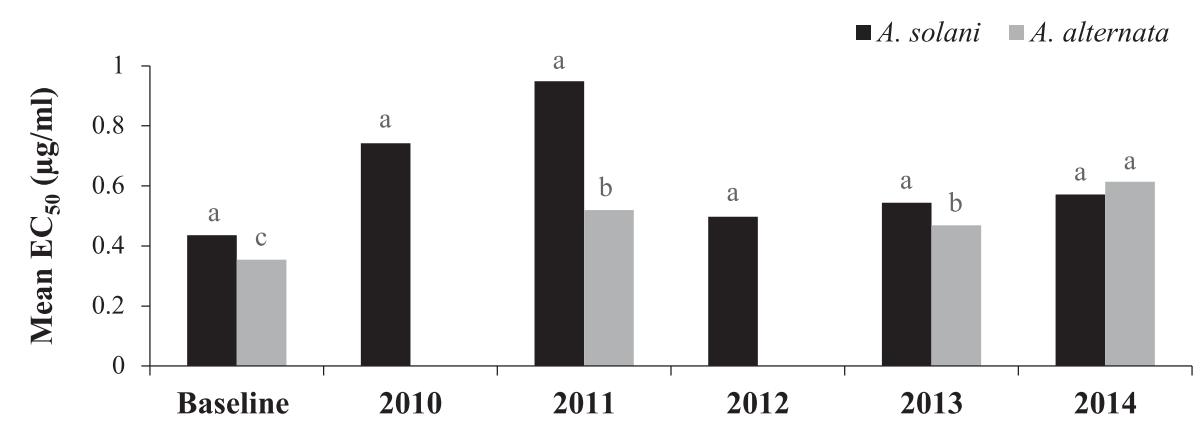

Fig. 5. Mean $\mathrm{EC}_{50}$ (the effective concentration at which the fungal growth is inhibited by $50 \%$ ) values for in vitro isolate sensitivity of Alternaria solani and Alternaria alternata to pyrimethanil across years. Within species, columns with the same letter are not significantly different, based on Fisher's protected least significant difference at the $P=0.05$ level.

Table 2. Origin of Alternaria solani isolates determined to be reduced-sensitive to pyrimethanil in the in vitro assessment

\begin{tabular}{lllrr}
\hline Isolate & Origin & Cultivar & Collection year & $\mathbf{E C}_{\mathbf{5 0}}^{\mathbf{z}}\left(\boldsymbol{\mu g} / \mathbf{m l}^{\mathbf{l}}\right)$ \\
\hline $1169-4$ & Acequia, ID & Unknown & 2010 & 2.06 \\
$1172-8$ & Acequia, ID & Unknown & 2010 & 1.77 \\
$1184-14$ & Wray, CO & FL 1867 & 2011 & 3.70 \\
$1191-13$ & Wadena, MN & Unknown & 2011 & 28.26 \\
$1226-12$ & Dalhart, TX & FL 1867 & 2011 & 4.10 \\
$1332-6$ & Dalhart, TX & Russet Norkotah & 2013 & 2.42 \\
\hline
\end{tabular}

${ }^{\mathrm{z}} \mathrm{EC}_{50}=$ the effective concentration at which the fungal growth is inhibited by $50 \%$. 
protectant fungicides such as chlorothalonil and mancozeb are used in fungicide rotation programs (Yellareddygari et al. 2016). Regardless, these results do not necessarily indicate that the pathogen populations may not shift toward DMI resistance in the future.

FRAC states that it is wise to accept that cross-resistance is present among DMI fungicides active against the same fungus. Examples of cross-resistance among the same chemical class have been reported in Alternaria spp. and other closely related fungi, so there is a high risk for cross-resistance between these two DMI fungicides in A. solani and A. alternata (Gudmestad et al. 2013; Pasche et al. 2004, 2005). However, given the fact that $A$. solani developed resistance against fungicides with single modes of action quite rapidly, it is highly likely that sequential use of these two DMIs in the same fungicide regime may increase the selection pressure on the pathogen population (Thomas et al. 2012). In this study, the correlation coefficient comparing $\mathrm{EC}_{50}$ values for difenoconazole and metconazole baseline sensitivities of $A$. solani isolates was very low. The difference in $\mathrm{EC}_{50}$ values of the two fungicides may be due to either the intrinsic activity of each fungicide, the genetic control of the variation in sensitivity to the two DMI fungicides, or both, despite having the same mode of action (Gubler et al. 1996). Currently, DMI fungicides are applied as mixtures to reduce the shift toward fungicide insensitivity. Difenoconazole is registered for use on potato in combination with mandipropamid as Revus Top (Syngenta Crop Protection) and metconazole as Quash (Valent U.S. A. Corporation). Difenoconazole has a limitation of no more than two consecutive applications before rotating to an alternate mode of action and metconazole has a restriction of two applications per season (Friskop et al. 2015). Increased risk of reducedsensitivity toward difenoconazole, has been reported in $\mathrm{V}$. inaequalis populations in Uruguay (Mondino et al. 2015). In that study, Rf values of 6.6 and 11.7 were reported in apple orchards with moderate (up to four applications per season) and intensive use (more than five applications per season) of the DMI chemistry, respectively.
Reduced sensitivity of A. solani and A. alternata to pyrimethanil was first detected in field isolates collected in 2010 from Idaho (Fairchild et al. 2013). In that study, four of 21 A. solani and one of nine A. alternata isolates were reported as resistant, although $\mathrm{EC}_{50}$ values were reported only for two isolates. The spiral gradient dilution method, an alternative to the classical 'poison agar' plating technique, was utilized to determine in vitro fungicide sensitivity of those isolates from Idaho. Despite the use of an alternative fungicide sensitivity screening method, potato dextrose agar, a complex media was used for the in vitro assays. The use of complex media instead of synthetic media might have had inhibitory effects on pyrimethanil, as a previous study has demonstrated that the activity of AP fungicides in fungicide sensitivity assays is low when complex media are used (Hilber and Schüepp 1996). The use of complex media, along with small sample size, may have contributed to the detection of relatively high frequency of resistance in the Idaho pathogen population. In the study reported here, 109 A. alternata isolates recovered from across all locations and years that were tested for sensitivity to pyrimethanil were found to still be sensitive to the fungicide. Additionally, only six of $245 \mathrm{~A}$. solani isolates exhibited reduced sensitivity to the AP fungicide, a frequency of only $2.4 \%$ and much lower than previously reported by Fairchild et al. (2013). These isolates demonstrated approximately four- to 64 -fold loss in sensitivity compared with the baseline population.

As expected, the level of disease control loss was consistent with the $\mathrm{EC}_{50}$ values obtained from in vitro sensitivity assays. Pyrimethanil provided similar levels of control of early blight disease caused by the two sensitive $A$. solani isolates, which was significantly superior to the control provided on reduced-sensitive isolates. Reducedsensitive isolates were not controlled by pyrimethanil except at the highest concentration. In this study, the term 'reduced-sensitivity' was used, instead of resistance, to describe the shift in sensitivity. Resistance to a specific fungicide should equate to a $100 \%$ loss of disease control at every concentration tested, demonstrating the fungicide would be of no value to the potato grower (Pasche et al. 2004). The

Table 3. Mean in vivo percentage disease control of Alternaria solani isolates by pyrimethanil as determined in greenhouse assays

\begin{tabular}{|c|c|c|c|c|c|c|c|}
\hline \multirow[b]{2}{*}{ Isolate } & \multirow[b]{2}{*}{$\mathrm{EC}_{50} \mathrm{w}(\mu \mathrm{g} / \mathrm{ml})$} & \multirow[b]{2}{*}{ Sensitive/reduced-sensitive $e^{x}$} & \multicolumn{4}{|c|}{ Pyrimethanil concentration $(\mu \mathrm{g} / \mathrm{ml})$} & \multirow[b]{2}{*}{ AUDRCy } \\
\hline & & & 0.1 & 1 & 10 & 100 & \\
\hline $13-1$ & 0.52 & $\mathrm{~S}$ & $7.4 \mathrm{a}$ & $37.0 \mathrm{a}$ & 88.9 a & $94.8 \mathrm{a}$ & $8,854.5 \mathrm{a}$ \\
\hline $1179-3$ & 0.75 & S & $5.5 \mathrm{ab}$ & $32.3 \mathrm{~b}$ & $89.4 \mathrm{a}$ & $96.4 \mathrm{a}$ & $8,927.4 \mathrm{a}$ \\
\hline $1168-3$ & 1.57 & RS & $5.0 \mathrm{~b}$ & $28.2 \mathrm{c}$ & $64.7 \mathrm{c}$ & $90.7 \mathrm{~b}$ & $7,427.1 \mathrm{c}$ \\
\hline $1184-14$ & 3.70 & $\mathrm{RS}$ & $2.2 \mathrm{c}$ & $22.2 \mathrm{~d}$ & $63.6 \mathrm{c}$ & $91.0 \mathrm{~b}$ & $7,355.6 \mathrm{c}$ \\
\hline $1191-13$ & 28.26 & $\mathrm{RS}$ & $3.7 \mathrm{bc}$ & $11.5 \mathrm{f}$ & $60.9 \mathrm{c}$ & $91.1 \mathrm{~b}$ & $7,171.5 \mathrm{~d}$ \\
\hline $1332-6$ & 2.42 & RS & $2.4 \mathrm{c}$ & $18.0 \mathrm{e}$ & $69.5 \mathrm{~b}$ & $91.1 \mathrm{~b}$ & $7,932.3 \mathrm{~b}$ \\
\hline $\operatorname{LSD}_{P=0.05^{\mathrm{z}}}$ & & & 2.1 & 3.1 & 4.1 & 1.8 & 171.7 \\
\hline
\end{tabular}

${ }^{\mathrm{w}} \mathrm{EC}_{50}$ (the effective concentration at which the fungal growth is inhibited by 50\%) values were obtained for pyrimethanil from the in vitro assessment.

${ }^{x}$ Isolates were characterized as sensitive (S) or reduced-sensitive (RS) based on resistance factor values $(\mathrm{S}=\leq 4, \mathrm{RS}=>4)$.

y $\mathrm{AUDRC}=$ Area under dose response curve.

${ }^{\mathrm{z}}$ Least significant difference at the $P=0.05$ level.

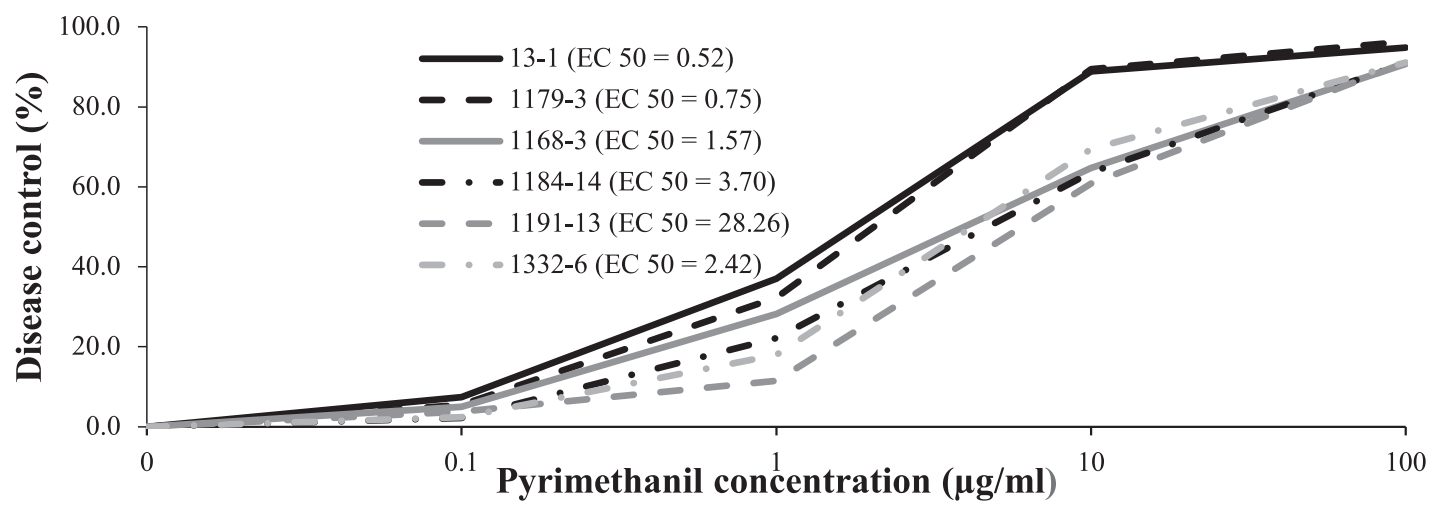

Fig. 6. Mean in vivo percentage disease control of Alternaria solani isolates by pyrimethanil as determined in greenhouse assays. 
in vivo data of this study do not portray a total loss of disease control; hence, the use of the term reduced-sensitivity to reflect the shift in sensitivity of the A. solani population in response to pyrimethanil.

The single-site mode of action of AP fungicides has been suggested to result in the inhibition of the secretion of fungal hydrolytic enzymes essential during infection as well as interfere with biosynthesis of methionine (Heye et al. 1994; Masner et al. 1994). Pyrimethanil as well as other AP fungicides cyprodinil and mepanipyrim are considered to be medium risk chemistries in the development of fungicide resistance in fungal pathogens (FRAC 2015). However, resistance to AP fungicides has been reported in B. cinerea (Amiri et al. 2013; Chapeland et al. 1999; Fernández-Ortuño et al. 2013; Hilber and Hilber-Bodmer 1998; Latorre et al. 2002; Leroux et al. 1999; Moyano et al. 2004; Myresiotis et al. 2007; Sun et al. 2010), Oculimacula spp. (Leroux et al. 2013), Penicillium digitatum and Penicillium expansum of apple and citrus, respectively, (Kanetis et al. 2008; Xiao et al. 2011), and $V$. inaequalis of apple (FRAC 2015).

$B$. cinerea, one of the most important phytopathogenic fungi, is considered to be a high-risk pathogen for fungicide resistance development and resistance to AP fungicides is common in some field crops and greenhouses (Brent and Holloman 2007b). Different phenotypes of AP resistance have been detected, particularly in $B$. cinerea, with resistance levels varying from low to very high (Leroux et al. 1999; Myresiotis et al. 2007). Cross-resistance in B. cinerea has also been reported among the three fungicides within the AP class (Hilber and Schüepp 1996; Latorre et al. 2002; Myresiotis et al. 2007). B. cinerea has a high risk of AP resistance development due to resistant isolates demonstrating to be fit as sensitive isolates, based on parameters of lesion growth and sporulation (FernándezOrtuño et al. 2013; Moyano et al. 2004). Genetic information is a crucial element in determining resistance risk to AP fungicides in $B$. cinerea populations. Genetic analysis of Botryotinia fuckeliana, the teleomorph of $B$. cinerea, indicated that resistance to AP fungicides segregated in a 1:1 ratio, and therefore, the gray mold pathogen displays a high inherent resistance risk to this specific chemistry, due to its monogenic resistance (Chapeland et al. 1999; Hilber and Hilber-Bodmer 1998). It is believed that the single-gene mode of resistance resulted in approximately $50 \%$ resistant isolates in some research studies focused on AP resistance in B. cinerea (Amiri et al. 2013; Fernández-Ortuño et al. 2013; Myresiotis et al. 2007). This major gene resistance reported in $B$. cinerea suggests that change in sensitivity should be rapid once resistant strains were detected. In contrast, field isolate Oculimacula spp. (formerly Tapesia spp.) displayed a gradual shift in sensitivity, suggesting polygenic control of resistance (Babij et al. 2000). This implies that there might be more than one mechanism of AP resistance in Alternaria spp.

The research reported here lays the groundwork for monitoring the shift in sensitivity in A. solani and A. alternata to difenoconazole, metconazole, and pyrimethanil, thereby evaluating the efficacy of resistance management programs for these pathogens in intensive production systems. It is important to collect additional pathogen isolates from potato production regions to monitor sensitivity to those fungicides. Monitoring studies will be valuable for continuous use of those chemistries in disease management programs. The two DMI fungicides and pyrimethanil should be used in rotation with other systemic and protectant fungicides, to safeguard their efficacy. The risk of resistance to pyrimethanil developing in A. solani may be increased because of pre-existing resistance to QoIs and boscalid. The A. solani isolates that demonstrated reduced sensitivity to pyrimethanil in this study also contain mutations that confer resistance to strobilurins and boscalid (Mallik et al. 2014). The qualitative nature of resistance may be the reason for reduced sensitivity toward pyrimethanil. Similar changes in population sensitivity have been observed for QoIs and SDHIs (Brent and Holloman 2007b). Qualitative resistance is defined as a sudden and marked loss of efficacy and the presence of a definite sensitive and resistant target population with extensively differing responses (Brent and Holloman 2007a). The primary mode of action is yet undiscovered for AP chemistries; therefore, the resistance mechanism is currently unknown for this established fungicide group.

\section{Acknowledgments}

We thank K. Chittem and C. Doetkott for statistical consultation; M. Bauske, $\mathrm{S}$. Budde, and $\mathrm{V}$. Johansen for assistance in performing laboratory and greenhouse assays; and R. Taylor for critically reviewing the manuscript. Financial support from Bayer CropScience, Syngenta Crop Protection, and Valent U.S.A. Corporation is gratefully acknowledged.

\section{Literature Cited}

Amiri, A., Heath, S. M., and Peres, N. A. 2013. Phenotypic characterization of multifungicide resistance in Botrytis cinerea isolates from strawberry fields in Florida. Plant Dis. 97:393-401.

Aradhya, M. K., Chan, H. M., and Parfitt, D. E. 2001. Genetic variability in the pistachio late blight fungus, Alternaria alternata. Mycol. Res. 105:300-306.

Avenot, H. F., and Michailides, T. J. 2007. Resistance to boscalid fungicide in Alternaria alternata isolates from pistachio in California. Plant Dis. 91:1345-1350.

Babij, J., Zhu, Q., Brain, P., and Hollomon, D. W. 2000. Resistance risk assessment of cereal eyespot, Tapesia yallundae and Tapesia acuformis, to the anilinopyrimidine fungicide, cyprodinil. Eur. J. Plant Pathol. 106:895-905.

Bolton, M. D., Rivera-Varas, V., del Río Mendoza, L. E., Khan, M. F. R., and Secor, G. A. 2012. Efficacy of variable tetraconazole rates against Cercospora beticola isolates with differing in vitro sensitivities to DMI fungicides. Plant Dis. 96:1749-1756.

Bouwman, J., Strypstein, C., Meier-Runge, F., and Gozalez, F. 2011. Revus Top: A new product for the control of P. infestans and Alternaria in potatoes in Europe. Pages 123-130 in: Proc. Thirteenth EuroBlight Workshop. St. Petersburg, Russia.

Brent, K. J., and Holloman, W. D. 2007a. Fungicide resistance in crop pathogens: How can it be managed? $2^{\text {nd }}$ Rev. Edn. Online. Fungicide Resistance Action Committee (FRAC), CropLife Int'l., Brussels, Belgium.

Brent, K. J., and Holloman, W. D. 2007b. Fungicide resistance in crop pathogens: The assessment of risk. 2nd Rev. Edn. Online. Fungicide Resistance Action Committee (FRAC), CropLife Int'l., Brussels, Belgium.

Chapeland, F., Fritz, R., Lanen, C., Gredt, M., and Leroux, P. 1999. Inheritance and mechanisms of resistance to anilinopyrimidine fungicides in Botrytis cinerea (Botryotinia fuckeliana). Pestic. Biochem. Physiol. 64:85-100.

Daniels, A., and Lucas, J. A. 1995. Mode of action of the anilino-pyrimidine fungicide pyrimethanil. 1. In-vivo activity against Botrytis fabae on broad bean (Vicia faba) leaves. Pestic. Sci. 45:33-41.

Fairchild, K. L., Miles, T. D., and Wharton, P. S. 2013. Assessing fungicide resistance in populations of Alternaria in Idaho potato fields. Crop Prot. 49:31-39.

Fernández-Ortuño, D., Chen, F., and Schnabel, G. 2013. Resistance to cyprodinil and lack of fludioxonil resistance in Botrytis cinerea isolates from strawberry in North and South Carolina. Plant Dis. 97:81-85.

Franc, G. D., and Christ, B. J. 2001. Early blight. Pages 22-23 in: Compendium of Potato Diseases. W. R. Stevenson, R. Loria, G. D. Franc, and D. P. Weingartner, eds. American Phytopathological Society, St. Paul, MN.

Friskop, A., Markell, S. G., and Khan, M. 2015. North Dakota Field Crop Fungicide Guide. North Dakota State University Cooperative Extension Service Bulletin PP-622. North Dakota State University, Fargo, North Dakota.

Fungicide Resistance Action Committee. 2015. FRAC Code List. Fungicides sorted by mode of action (including FRAC code numbering). Online publication. CropLife Int'l., Brussels, Belgium.

Gubler, W. D., Ypema, H. L., Ouimette, D. G., and Bettiga, L. J. 1996. Occurrence of resistance in Uncinula necator to triadimefon, mycoblutanil, and fenarimol in California grapevines. Plant Dis. 80:902-909.

Gudmestad, N. C. S., Arabiat, S., Pasche, J. S., and Miller, J. S. 2013. Prevalence and impact of SDHI fungicide resistance in Alternaria solani. Plant Dis. 97: 952-960.

Heye, U. J., Speich, J., Siegle, H., Steinemann, A., Forster, B., Knauf-Beiter, G., Herzog, J., and Hubele, A. 1994. CGA 219417: A novel broad-spectrum fungicide. Crop Prot. 13:541-549.

Hilber, U. W., and Hilber-Bodmer, M. 1998. Genetic basis and monitoring of resistance of Botryotinia fuckeliana to anilinopyrimidines. Plant Dis. 82: 496-500.

Hilber, U. W., and Schüepp, H. 1996. A reliable method for testing the sensitivity of Botryotinia fuckeliana to anilinopyrimidines in vitro. Pestic. Sci. 47:241-247.

Holm, A. L., Rivera, V. V., Secor, G. A., and Gudmestad, N. C. 2003. Temporal sensitivity of Alternaria solani to foliar fungicides. Am. J. Potato Res. 80: $33-40$.

Jutsum, A. R., Heaney, S. P., Perrin, B. M., and Wege, P. J. 1998. Pesticide resistance: assessment of risk and the development and implementation of effective management strategies. Pestic. Sci. 54:435-446.

Kanetis, L., Förster, H., Jones, C. A., Borkovich, K. A., and Adaskaveg, J. E. 2008 Characterization of genetic and biochemical mechanisms of fludioxonil and pyrimethanil resistance in field isolates of Penicillium digitatum. Phytopathology 98:205-214

Keinath, A. P., and Hansen, Z. R. 2013. Isolates of Didymella bryoniae from South Carolina remain sensitive to DMI fungicides despite multiyear exposure. J. Phytopathol. 161:315-323.

Köller, W., Wilcox, W. F., and Parker, D. M. 2005. Sensitivity of Venturia inaequalis populations to anilinopyrimidine fungicides and their contribution to scab management in New York. Plant Dis. 89:357-365. 
Latorre, B. A., Spadaro, I., and Rioja, M. E. 2002. Occurrence of resistance strains of Botrytis cinerea to anilinopyrimidine fungicides in table grapes in Chile. Crop Prot. 21:957-961.

Leroux, P., Chapeland, F., Desbrosses, D., and Gredt, M. 1999. Patterns of crossresistance to fungicides in Botryotinia fuckeliana (Botrytis cinerea) isolates from French vineyards. Crop Prot. 18:687-697.

Leroux, P., Gredt, M., Remuson, F., Micoud, A., and Walker, A. S. 2013. Fungicide resistance status in French populations of the wheat eyespot fungi Oculimacula acuformis and Oculimacula yallundae. Pest Manag. Sci. 69: 15-26.

Mallik, I., Arabiat, S., Pasche, J. S., Bolton, M. D., Patel, J. S., and Gudmestad, N. C. 2014. Molecular characterization and detection of mutations associated with resistance to succinate dehydrogenase-inhibiting fungicides in Alternaria solani. Phytopathology 104:40-49.

Masner, P., Muster, P., and Schmid, J. 1994. Methionine biosynthesis inhibition by pyrimidinamine fungicides in Botrytis cinerea. Pestic. Sci. 42:163-166.

McKay, A. H., Förster, H., and Adaskaveg, J. E. 2012. Toxicity and resistance potential of selected fungicides to Galactomyces and Penicillium spp. causing postharvest fruit decays of citrus and other crops. Plant Dis. 96:87-96.

Milliken, G. A., and Johnson, D. E. 1992. One-way treatment structure in a completely randomized design with heterogeneous errors. Pages 16-28 in: Analysis of Messy Data. Vol. I Designed Experiments. Chapman and Hall, London.

Mondino, P., Casanova, L., Celio, A., Bentancur, O., Leoni, C., and Alaniz, S. 2015. Sensitivity of Venturia inaequalis to Trifloxystrobin and Difenoconazole in Uruguay. J. Phytopathol. 163:1-10.

Moyano, C., Gomez, V., and Melgarejo, P. 2004. Resistance to pyrimethanil and other fungicides in Botrytis cinerea populations collected in vegetable crops in Spain. J. Phytopathol. 152:484-490.

Myresiotis, C. K., Karaoglanidis, G. S., and Tzavella-Klonari, K. 2007. Resistance of Botrytis cinerea isolates from vegetable crops to anilinopyrimidine, phenylpyrrole, hydroxyanilide, benzimidazole, and dicarboximide fungicides. Plant Dis. 91:407-413.

Nnodu, E. C., Harrison, M. D., and Parke, R. V. 1982. The effect of temperature and relative humidity on wound healing and infection of potato tubers by Alternaria solani. Am. Potato J. 59:297-311.

Olaya, G., Cochran, A., and Gudmestad, N. C. 2010. Difenoconazole baseline sensitivity distribution of Colletotrichum coccodes isolates from potatoes. (Abstr.). Phytopathology 100:S93.

Pasche, J. S., and Gudmestad, N. C. 2008. Prevalence, competitive fitness and impact of the F129L mutation in Alternaria solani from the United States. Crop Prot. 27:427-435.

Pasche, J. S., Wharam, C. M., and Gudmestad, N. C. 2004. Shift in sensitivity of Alternaria solani in response to QoI fungicides. Plant Dis. 88:181-187.

Pasche, J. S., Piche, L. M., and Gudmestad, N. C. 2005. Effect of the F129L mutation in Alternaria solani on fungicides affecting mitochondrial respiration. Plant Dis. 89:269-278.

Rotem, J. 1994. The Genus Alternaria: Biology, Epidemiology, and Pathogenicity. American Phytopathological Society, St. Paul, MN.

Russell, P. E. 2005. A century of fungicide evolution. J. Agric. Sci. 143:11-25.

Shaner, G., and Finney, R. E. 1977. The effect of nitrogen fertilization on the expression of slow-mildewing resistance in Knox wheat. Phytopathology 67: 1051-1056.

Sholberg, P. L., Bedford, K., and Stokes, S. 2005. Sensitivity of Penicillium spp. and Botrytis cinerea to pyrimethanil and its control of blue and gray mold of stored apples. Crop Prot. 24:127-134.
Skylakakis, G. 1982. The development and use of models describing outbreaks of resistance to fungicides. Crop Prot. 1:249-262.

Smith, F. D., Parker, D. M., and Köller, W. 1991. Sensitivity distribution of Venturia inaequalis to the sterol demethylation inhibitor flusilazole: baseline sensitivity and implications for resistance monitoring. Phytopathology 81:392-396.

Spolti, P., Del Ponte, E. M., Dong, Y., Cummings, J. A., and Bergstrom, G. C. 2014. Triazole sensitivity in a contemporary population of Fusarium graminearum from New York wheat and competitiveness of a tebuconazoleresistant isolate. Plant Dis. 98:607-613.

Stevenson, W. R., and James, R. V. 1999. Evaluation of fungicides to control early blight and late blight of potato, Hancock, 1998. Fungic. Nematicide Tests 54 212-213.

Sun, H.-Y., Wang, H.-C., Chen, Y., Li, H.-X., Chen, C.-J., and Zhou, M.-G. 2010 Multiple resistance of Botrytis cinerea from vegetable crops to carbendazim, diethofencarb, procymidone, and pyrimethanil in China. Plant Dis. 94: 551-556.

Thomas, A., Langston, D. B., Jr., and Stevenson, K. L. 2012. Baseline sensitivity and cross-resistance to succinate-dehydrogenase-inhibiting and demethylationinhibiting fungicides in Didymella bryoniae. Plant Dis. 96:979-984.

Tymon, L., and Johnson, D. A. 2014. Fungicide resistance of two species of Alternaria from potato in the Columbia Basin of Washington. Plant Dis. 98 $1648-1653$

van der Waals, J. E., Korsten, L., and Slippers, B. 2004. Genetic diversity among Alternaria solani isolates from potatoes in South Africa. Plant Dis. 88:959-964.

Villani, S. M., Biggs, A. R., Cooley, D. R., Raes, J. J., and Cox, K. 2015. Prevalence of myclobutanil resistance and difenoconazole insensitivity in populations of Venturia inaequalis. Plant Dis. 99:1526-1536.

Wharton, P., Fairchild, K., Belcher, A., and Wood, E. 2012. First report of in-vitro boscalid-resistant isolates of Alternaria solani causing early blight of potato in Idaho. Plant Dis. 96:454

Wong, F. P., and Midland, S. L. 2007. Sensitivity distributions of California populations of Colletotrichum cereale to the DMI fungicides propiconazole, myclobutanil, tebuconazole, and triadimefon. Plant Dis. 91:1547-1555.

Wong, F. P., and Wilcox, W. F. 2002. Sensitivity to azoxystrobin among isolates of Uncinula necator: Baseline distribution and relationship to myclobutanil sensitivity. Plant Dis. 86:394-404.

Woudenberg, J. H. C., Seidl, M. F., Groenewald, J. Z., de Vries, M., Stielow, J. B., Thomma, B. P. H. J., and Crous, P. W. 2015. Alternaria section Alternaria: Species, formae speciales or pathotypes? Stud. Mycol. 82:1-21.

Xiao, C. L., Kim, Y. K., and Boal, R. J. 2011. First report of occurrence of pyrimethanil resistance in Penicillium expansum from stored apples in Washington State. Plant Dis. 95:72.

Yang, J. H., Brannen, P. M., and Schnabel, G. 2015. Resistance in Alternaria alternata to SDHI fungicides causes rare disease outbreak in peach orchards. Plant Dis. 99:65-70.

Yellareddygari, S. K. R., Pasche, J. S., Taylor, R. J., and Gudmestad, N. C. 2016 Individual participant data meta-analysis of foliar fungicides applied for potato early blight management. Plant Dis. 100:200-206.

Yin, Y. N., Kim, Y. K., and Xiao, C. L. 2011. Molecular characterization of boscalid resistance in field isolates of Botrytis cinerea from apple. Phytopathology 101:986-995.

Zhao, H., Kim, Y. K., Huang, L., and Xiao, C. L. 2010. Resistance to thiabendazole and baseline sensitivity to fludioxonil and pyrimethanil in Botrytis cinerea populations from apple and pear in Washington State. Postharvest Biol. Technol. 56:12-18. 